\title{
O solteiro, o porco inteiro, o caçador sem caça: o "um" entre os Araweté
}

DOI

http://dx.doi.org/10.11606/ 2179-0892.ra.2017.137316

\author{
Camila Becattini Pereira de Caux \\ - Universidade Federal do Rio de Janeiro / Rio de Janeiro, RJ, Brasil \\ $\checkmark$ camilacaux@gmail.com
}

\section{RESUMO}

O artigo se dedica a descrever aspectos do universo dos jijehã - isto é, das solteiras e dos solteiros - entre os Araweté, povo habitante do médio curso do rio Xingu (PA), falante de um idioma da família linguística tupi-guarani. Em um local onde o núcleo da socialidade adulta é o casal, refletiremos em que sentido a condição de não-casado pode ser encarada como um "negativo" de tal estado. A partir de uma análise de usos coloquiais da partícula jije, exploraremos como solteiros podem ser considerados "singularidades" compostas por uma "relação de ausência" - não tendo travado uma aliança conjugal específica, podem virtualmente travar uma multiplicidade de relações. Seguiremos daí um pouco da trama relacional dos jovens, refletindo sobre a mobilidade de que são investidos. palavras-chave

Etnologia amazônica, Araweté, solteiros, flertes, parentesco. 
Diz-se, entre os Araweté - povo que fala um idioma da família tupi-guarani e habita atualmente o médio curso do rio Xingu' - que um jijehã é tsipe. Jijehã é a palavra araweté para solteiro ou solteira, tsipe designa o numeral "um". É para a associação entre estes termos que o presente artigo irá se voltar.

Quero aqui me debruçar particularmente sobre as formas de relações dos solteiros e solteiras araweté - algo que, até onde vai meu conhecimento, não foi foco de muita atenção nos estudos ameríndios. É verdade que muitas etnografias trazem apontamentos sobre tais personagens. É normal que se dediquem à descrição de rituais de passagem (como no caso da menarca, para meninas, ou da primeira caça ou perfurações corporais, para meninos) ou de questões próprias ao estabelecimento de alianças (como escolhas ou prescrições matrimoniais, transição para a vida conjugal etc). De fato, algo de fundamental sobre esta condição é que ela é "passageira" - cedo ou tarde (exceto em contextos históricos específicos, onde há escassez de cônjuges possíveis), os jovens crescerão e se casarão. Assim, as etnografias usualmente descrevem o que há de transitório nesse momento. Todavia, minha impressão é que pode haver algo de interessante na constituição mesma dessa transitoriedade.

No caso araweté, a condição de jijehã chamou-me particularmente a atenção. Ali não há rituais de iniciação para a vida adulta. A maturidade é alcançada a partir do casamento e, sobretudo, do nascimento do primogênito. Mas, embora jovens não-casados não sejam encarados inteiramente como adultos, eles possuem preocupações e um cotidiano muito diferentes daqueles das crianças mais novas. Ademais, o próprio termo jijehã, como veremos, é rico de significações, que têm muito a informar sobre a socialidade araweté como um todo.

Os solteiros e solteiras são tsipe. Este, como mencionei, é o numeral "um". Todavia, ele também é o termo utilizado para dizer que alguém está "sozinho". Já o numeral seguinte é mukũĩ "dois", e não casualmente ele é também a palavra usada para se referir ao "casal". Começarei este artigo analisando os usos coloquiais da partícula jije, percebendo em que sentido solteiros podem ser considerados como "singularidades" compostas por uma "relação de ausência": não tendo travado uma aliança conjugal, eles podem virtualmente travar uma multiplicidade de relações. Seguirei descrevendo a grande mobilidade de que esses jovens são investidos, com o fim de discutir em que sentido o significado "sozinho" do termo tsipe é uma descrição da condição celibatária. Veremos, enfim, que ali onde o casal é o núcleo da socialidade adulta, o estado jijehã é como um "negativo" dele.

\section{O JUNTO E O SEPARADO}

Jijehã - do qual não pude encontrar cognatos em outros idiomas da família
1 Os Araweté contavam em 2014 (Censo DSEI-

Altamira/2014) com uma população de 448 indivíduos. Distribuem-se entre as sete atuais aldeias na Terra Indígena Araweté/lpixuna, demarcada em 1992 e homologada em 1996 com a extensão de 940.900 ha. Realizei meu trabalho de campo na aldeia Juruãti, sobretudo entre os anos de 2011 e 2014, tendo contado com o auxílio Projeto "Ontografia comparativa e equivocação controlada: novos estudos etnográficos" (no âmbito do MCTI/CNPq no 14/2012) e do PPGAS/MN e Capes (com os auxílios de 2011/2 e 2013/1). O presente artigo é uma versão modificada de um dos capítulos de minha tese de doutorado, que resultou daquela pesquisa. Agradeço às/aos pareceristas pelos valiosos comentários, bem como a Eric Macedo, Guilherme Heurich e Luisa Girardi pelas leituras e sugestões. 
tupi-guarani - não é um termo simples. A primeira coisa que posso notar sobre ele é que ele é divisível em dois morfemas, jije e -hã.-Hã é um sufixo formador de nomes de agentes e objetos ou de nomes de circunstâncias (Solano, 2010), mas em alguns casos - como, parece-me, o aqui analisado - o resultado da nominalização manifesta uma característica arquetípica. Há, como exemplo, a figura clássica do Dono da água que, no idioma atual dos Araweté, é comumente chamado de Iwikatihã. I wikati é o nome do substrato inferior ao que vivemos, onde, embora muitos seres o habitem, o Dono da água é o que carrega o sufixo - hã acrescido ao nome do local. Essa marcação linguística aponta para uma predominância que é também conceitual: o Iwikatihã é uma transformação da cobra-grande (mai-aho), e os outros habitantes do mundo inferior são, em grande maioria, seus xerimbabos (demima). No caso do solteiro, o acréscimo do hã ao jije parece atribuir à condição celibatária uma característica também emblemática, sendo assim jijehã o uso mais corriqueiro do jije.

Devemos, em todo caso, entender os outros usos de jije, de modo a entender o sentido informado pela sua junção ao sufixo. A primeira vez que ouvi a palavra isolada do sufixo (e, portanto, fora do uso comum de jijehã) foi quando procurava, em uma tarde de estudos da língua com minha amiga Kunirikoti, um equivalente no idioma dos Araweté para "panema". Após a pergunta, minha amiga refletiu por alguns instantes e me disse enfim que tal palavra não existia, mas me forneceu uma versão que Ihe pareceu traduzir apropriadamente a ideia. Ela disse que, quando um homem chega à aldeia sem caça, ele fala para a mulher: jije hetete, "estou jije à toa". Escutei depois formas alternativas, como jije ku he rodzi, "eu vim jije", ou jije hetete hero re'e, "eu cheguei jije à toa". Em todos esses casos, os Araweté me traduziam essa partícula por "sem nada", "sem" e às vezes por "sozinho" (como em "voltou sozinho").

A relação entre a caça e o jije ainda tomará nossa atenção, mas por enquanto devemos nos ater a traduções análogas da partícula. Uma delas se dá quando alguém não toma parte em uma distribuição, e isso pode ser dito para qualquer bem. Um caso que ocorreu durante meu campo é ilustrativo. No contexto da construção da Usina Hidrelétrica de Belo Monte, quando a Norte Energia já havia recebido a Licença de Instalação sem ter iniciado o Plano Básico Ambiental, a empresa colocou em operação um "Plano Emergencial", que teria como objetivo iniciar algumas ações urgentes de compensação socioambiental. Na prática, essas ações se transformaram em enormes listas de mercadorias "oferecidas" pela empresa a todas as aldeias do Médio-Xingu-listas consideradas por muitos como um mecanismo da empresa para desmobilizar a pressão indígena contra a obra. Para além destas, uma série de outros itens foram negociados em acordos de desocupação de canteiros de obra, por ocasião de manifestações por parte dos povos indígenas da região ${ }^{2}$. Entre esses, constava a construção de novas ca-
2 Todas estas ações causaram impactos que não estavam previstos nos estudos realizados previamente à construção da barragem. Estes novos impactos ainda precisarão ser estudados de maneira sistemática a fim de que se constate a gravidade de seus efeitos. Para melhor informação sobre tais impactos, ver Ação Civil Pública do Ministério Público Federal, de 07.12.2015, assinada pelos Procuradores da República Thais Santi, Cynthia Arcoverde e Ubiratan Cazzeta. Pela minha experiência, é fato que o processo resultou numa mudança de hábitos de alimentação, de regularidade de visitas à cidade, do padrão de residência e da relação desses índios com a casa. 
sas, que acabaram obedecendo ao novo estilo regional (telha de brasilit, parede de madeira e chão de cimento), muito diferente do estilo predominante então (parede e chão de barro, telhado de palha de babaçu). Os Araweté optaram por ajudar a carregar o material (madeira, cimento, tijolos para a base e telhas), ganhando em troca um pagamento. Havia um valor total que seria ao fim dividido entre todos os que ajudaram. Nesse momento, todos os moradores (homens e mulheres) da aldeia trabalharam, exceto idosos e crianças, mas havia muitas vezes burburinhos e acusações, na maior parte das vezes veladas, questionando se tal ou tal pessoa receberia a quantia ou - eis novamente a partícula-se ficaria jije. O uso aqui, essencialmente relacional, indica alguém que não tomaria parte de uma distribuição geral, isto é, alguém que ficaria "sem" em referência a um conjunto de pessoas que teriam acesso ao valor total.

Outro uso corriqueiro da partícula dá-se em um contexto alimentar. A base vegetal da culinária araweté é o milho. Normalmente, uma boa refeição é composta por carne (mée ra’a) e "fubá" (awatsï mepi), o qual é obtido a partir de debulhamento, torração e pilagem dos grãos de milho em uma paçoca fina e seca. Ao comer-se a carne, acrescenta-se um pouco do fubá na boca, ação que me disseram chamar-se -tirõ, "combinar". O milho é o complemento da carneou talvez o contrário, como notou Viveiros de Castro (1986:164)-, pois ele pode ser comido puro, quando o mesmo não costuma ser feito com a carne. Hoje, a alimentação carnívora é complementada idealmente com awatsï mepi, mas, quando não o há, com farinha ou arroz. Quando não há carne em um pátio, come-se somente o complemento, e diz-se nesse caso que se come jije (jije mide o, "nós-inclusivo comemos jije"). A tradução aqui seria "sem carne" ou "puro". É possível também usar o termo jije ao comer carne sem o complemento, mas isso é para lá de incomum: se acabar a provisão vegetal em uma expedição de caça coletiva, os caçadores decidem voltar para casa, pois não vão comer "só carne" (Viveiros de Castro, 1986:164).

Há ainda outros usos que informam um sentido parecido aos que já mostrei. Por exemplo, quando alguém se vê desprovido de um bem que lhe é necessário: uma criança queria emprestado um item importante-especificamente, uma lanterna ao anoitecer - e teve seu pedido negado já que seu dono "ficaria sem" (jije uka). Ou para se referir a uma mulher pelada: quando um homem brincava que uma jovem (que, como todas as Araweté, sempre traja um tipo de anágua, mesmo quando não veste por cima a saia tradicional tupã̃i) ficava completamente sem roupas à noite, ele dizia jocosamente que ela jije uka, "ficava pelada".

As possibilidades de uso nesse sentido não faltam e parecem todas apontar para traduzirmos jije como "sem", mas em uma acepção que combina tal "ausência" com uma ideia de dissociação. Um caçador sem caça, um alimento sem o complemento, uma mulher sem vestes, alguém sem um objeto que lhe 
é necessário ou sem tomar parte de algo que lhe caberia - há em comum entre eles uma separação, um apartamento entre dois termos idealmente conexos. Trata-se então, a meu ver, de uma noção que comunica uma forma de relação, ou, mais apropriadamente, uma relação marcada pela disjunção. Se decidimos levar à frente essa tradução, um solteiro (jijehã) seria alguém a quem falta um elemento específico - ou, antes, constituído por uma "relação de ausência", pois separado de algo que potencialmente o compõe.

Sem descartar essa tradução, é necessário examinar o que mais há a dizer sobre o jije. Ensinaram-me também outra possibilidade do uso dessa partícula, que também pode ser aplicada - de modo diferente - à caça. Terei como referência especificadamente a caça de queixada, já que essa é considerada a principal base animal (junto com o jaboti) do cardápio araweté.

Dentre as excursões habituais de caçadas, há duas mais comuns, as coletivas e as individuais. Nestas últimas, um caçador parte sozinho da aldeia, às vezes impulsionado por pedido de sua esposa, às vezes porque visa um animal que demanda empresa individual, às vezes só porque quer partir muito cedo-algo que o ritmo próprio das ações coletivas não permitiria: de uma decisão inicial do homem que "lidera" (tenotã) a caçada à efetivação coletiva dela pode-se tomar algumas horas (ver Viveiros de Castro, 1986, cap. V.2). Em todo caso, quando vai sozinho, o caçador trará intacta a presa que conseguir: ele não irá cortá-la, poderá no máximo limpá-la. Diz-se então que ele a traz a caça jije, termo que me traduziram por "inteira”.

Mas a tradução por "inteiro" não é restrita à caça. Coisas "inteiras", "fechadas", podem ser ditas jije, e atualmente há um uso bastante corrente: o fardo de um alimento, isto é, a embalagem que agrupa várias unidades de um alimento industrializado. Um fardo de açúcar, por exemplo, é um embrulho de seis pacotes de cinco quilos desse alimento, que é dito hewo mée jije. É interessante que, desde que começaram a adquirir "ranchos" na cidade de Altamira, os Araweté tenham sempre preferido comprar fardos fechados. Nomeiam em contraposição o fardo aberto como dzarã mire, "mexido", ou huwaro mire, "pela metade", e a compra de produtos isolados como parã-parã mire, "misturado" (isto é, as várias mercadorias dentro de caixas, sacas etc.). Quando têm dinheiro, eles costumam levar para a aldeia invariavelmente as unidades maiores; quando não têm, acabam escolhendo alguns dentre os fardos que seu dinheiro pode comprar, ainda que para isso tenham que sacrificar a diversidade de produtos, ou levar só uma mescla de pequenos pacotes. Em todo caso, o mais importante a respeito de algo trazido inteiro é que, justamente, ele deverá ser "decomposto". Um fardo fechado deverá ser aberto, um porco íntegro deverá ser cortado - tudo inteiro, eis o ponto, será distribuído.

Voltemos à caça. Nas caçadas coletivas visando queixadas, os homens 
saem juntos da aldeia, atualmente partindo de voadeira - só os velhos, dizem, vão caçar "de pé". Geralmente, os homens se reúnem em mais de uma embarcação e se repartem segundo relações de parentesco e aliança, ou mesmo por inclinações afetivas momentâneas, oriundas de frequentamento nas refeições nos pátios uns dos outros. Todos os barcos-cada um a seu tempo - partem da aldeia e se encaminham a uma mesma região de caça, mesmo que nem sempre aportem no mesmo lugar. Ali, os homens se separam: assim como na caçada individual, cada homem andará sozinho e será responsável pela sua busca. Porém, diferentemente da caçada em que um homem parte só, aqui todos os frutos da caçada serão distribuídas na própria mata, antes do retorno à aldeia.

Justamente aqui a história se torna mais interessante. Com os animais reunidos, os homens cuidam de limpar e separar as bandas (iweje-re) dos animais - as pernas (i'o-pe), a coluna (ikupe-pe), a cabeça (zaxĩ-ñe), ou, quando há fartura, metades do porco, num corte longitudinal. Essa partilha fornece pedaços ainda grandes que, quando preparados e cozidos na aldeia, sofrerão uma nova distribuição entre os convidados a comer. Há um nome que pode descrever em conjunto esses pedaços que ainda serão decompostos na cocção: jijehã.

Quando partem em conjunto, todos os que tomaram parte da caçada receberão pedaços de carne. Isso, aliás, faz com que caçadores mais avaros decidam nem sempre tomar parte dessas empreitadas coletivas, pois delas participam também jovens se iniciando nas artes da caça, além de homens reputados não tão destros nas técnicas. De todo modo, a partilha normalmente compreende todos, embora os pedaços fartos - os jijehã - caibam normalmente a adultos com famílias grandes, que congregam visitantes em suas refeições. A decisão de quem convidar ao banquete depende de alguns cálculos, como a quantidade da carne disponível, as relações atuais com as famílias vizinhas (que podem estar mais ou menos próximas em função de rixas momentâneas), memória de convites anteriores feitos por outras famílias, pessoas passando em frente ao pátio na hora da refeição etc. Adultos com muitos filhos e lideranças geralmente concentram grupos maiores em seu pátio, compartilhando com outros núcleos residenciais partes cozidas da caça (ou, em tempos de fartura e quando se trata da cabeça, moqueadas). Recebem, portanto, pedaços que serão partilhados - ou melhor, novamente partilhados - na refeição.

Já os caçadores jovens, sem filhos ou com filhos ainda pequenos, podem receber pedaços menores. Nesse caso, pode-se dizer que eles voltaram da caçada jije ĩme'e (sendo que o ĩ funciona como uma negação predicativa do termo jije, e o me'e como um adjetivador que informa uma "coisa" ou "estado"). Jije ĩme'e te he, "estou não-jije", ou aro ku he jije ĩme'e, "trouxe um não-jije", diz um caçador à sua esposa quando traz somente um "pedacinho" (pẽễi) de carne, ou mesmo quan- 
do não traz nenhuma. Nesse caso, o jovem casal comerá na casa dos pais e/ou de vizinhos, mas não chamará ninguém para comer na sua. Se houver partilha, eles irão receber, e não dar. Note-se que a contraparte positiva de jije ĩ me'e - ou seja, jije me'e-denota justamente, no contexto da caçada de queixadas, o porco inteiro, não distribuído.

Recapitulemos. Um porco inteiro (de uma caçada coletiva tanto quanto individual) é jije (ou jije me’e). Mas há uma característica própria dessa caça: a de ser "distribuída", imohĩ mire. Se ela está inteira, é porque ainda não foi-e então será - imoi mire, "cortada", e destinada a determinados recipientes. Todavia, há uma quantidade finita e não uniforme de carne em um porco. A carcaça será decomposta em pedaços, mas eles não são iguais. Alguns deles serão passíveis de novas divisões, outros não. Um porco inteiro éjije, mas uma pata inteira é, ela também, jije. Já um "pedacinho", contrariamente, éjijeĩme’e, "não-jije".

É notável então que, quando se fala de porcos, a partícula jije é indissociável da noção de distribuição. Quando morta, a presa será distribuída em grandes partes cruas que, quando cozidas, serão novamente distribuídas durante a refeição. Outras famílias serão convidadas a se juntar e pegar "partes" de um mesmo bocado do porco, agora novamente decomposto na panela. É possível inclusive supor uma nova distribuição: segundo me ensinaram (embora isso nem sempre aconteça), o marido é o responsável por pegar pedaços da panela e entregar à sua esposa. Ela então distribuirá sua parte entre si e os filhos, às vezes também reservando o fragmento que cabe ao marido. Todavia, nunca vi ser usado o termo jije para essa porção que a esposa divide. Diz-se somente que ela recebe um "pedaço" (pẽhẽ), talvez porque, assim como o pedaço de carne crua distribuído a um homem sem filhos na mata, a partilha dentro do núcleo doméstico (casal e seus filhos) não consiste em "distribuição".

Quanto ao fardo, a lógica é semelhante. Se está inteiro, ele deverá eventualmente ser aberto e, quando o for, será foco de distribuição. Sua distribuição, é bem verdade, pode ser um tanto mais sensível à avareza. Não é incomum que um casal deixe fechado um fardo especialmente visado (como, por exemplo, 0 de refrigerante) ao chegar de Altamira, quando os ol hares interessados mereceriam seu bocado. Quando o fardo é aberto, ele é idealmente distribuído - pelo menos uma parte dele - aos mais próximos; todavia, há uma diferença importante em relação à caça: aqui, o termo jije não é usado para as unidades menores. Uma unidade (de $1 \mathrm{~kg}$ ou 5kg) de açúcar, arroz, óleo, por exemplo, não é jije - quando aberta, ela não é novamente distribuível, pois não existe a oferta de algo como um "punhado". Mesmo no caso de uma garrafa de refrigerante, que é cedido em canecas a outras pessoas, seu dono não tem obrigação de distribuir o conteúdo, nem mesmo de abrir a garrafa no momento mesmo em que a recebe. As embalagens unitárias são, então, a unidade mínima de distribuição de um 
fardo - o que não quer dizer que seus conteúdos não chegarão a outras pessoas quando convidadas a comer.

Assim, nessa acepção, jije indica, ao mesmo tempo, inteireza e fragmentação. Trata-se de uma unidade (um porco, um fardo) à qual é inerente sua distribuição (em pedaços, em sacos unitários de alimentos). É então uma singularidade que tende a se decompor, a se compartimentar em novas partes-que podem, elas também, se dividir. Nesse sentido, jije encarna uma multiplicidade, mas interna a uma singularidade. Dentro da unidade, há "zonas" que instanciam uma futura divisão, e que só serão diferenciadas quando for operado um corte, uma abertura.

Acabamos de ver dois tipos de uso da partícula jije. Por um lado, descrevi ocasiões em que algo é constituído por uma relação de ausência. O caçador (sem caça), a mulher (sem roupa), o fubá de milho (sem carne) estão destacados de um elemento que-mesmo que contextualmente-os compõe. São então definidos pela negatividade de uma relação. Alguém sem sua parcela de uma distribuição, ou desprovido de seu objeto necessário não é diferente. Jije, nesse sentido, é uma dissociação entre dois elementos. Há aqui uma disjunção entre termos idealmente correlatos: uma relação que encerra o ato mesmo da separação. Por isso mesmo, trata-se de elementos instáveis, pois parte de uma decomposição indevida.

Por outro, descrevi situações em que jije descreve singularidades, como a carcaça do porco ou um fardo, mas que são decomponíveis em partes menores. Trata-se de um "inteiro" que é uma multiplicidade não atualizada, e cuja instabilidade reside justamente em sua não-separação. Quando inteira, essa unidade contém virtualmente uma multiplicidade de relações - mas essa multiplicidade não pode se manter, se quer se atualizar. Um porco ou um pedaço, inteiros e crus, não são comestíveis; tampouco um alimento na embalagem. É necessária a divisão, e então a distribuição - mas essa distribuição irá necessariamente reduzir as possibilidades a um número finito: só certos pedaços dados a algumas pessoas. A atualização será a efetivação discriminatória da multiplicidade em um número, isto é, uma quantidade concreta de partes e de pessoas recipientes.

Esses são, assim parece, dois significados diferentes da uma mesma palavra. $O$ interessante é que, embora em sentidos diferentes, ambos parecem fundar-se em uma mesma relação: uma que informa uma dissociação inadequada (como a do caçador sem sua caça), outra que fala de uma separação que ainda se deve realizar (como a da caça inteira). Uma é descrita pelo intervalo entre dois termos que deveriam estar unidos. Outra pela continuidade entre partes que deverão ser separadas, na distribuição.

O curioso é que, mesmo tratando-se de dois significados opostos, ambos servem igualmente como qualificadores da ideia de solteiro. Vejamos um de cada vez. 
Que um solteiro seja alguém dissociado de seu par não é uma ideia de difícil compreensão. Thomas Gregor, por exemplo, afirmou que não haveria maneira melhor de compreender "the value of Mehinaku marriage" senão mirando o "pitiable bachelor" (1985: 25): um homem magro, dono de uma rede em trapos, sem lenha para aquecê-lo e privado da possibilidade de consumar determinados rituais - não muito diferente do solteiro "sombrio, malcuidado, terrivelmente magro e (...) no estado de mais completa abjeção" a quem Lévi-Strauss atribuíra grave doença (2011: 77). Uma descrição tão triste não caberia aos solteiros e solteiras araweté com quem convivi, mas isso não descarta a importância que o casamento tem nas práticas relacionais cotidianas desses índios. O celibato aqui também aparece como a contrapartida negativa do estado padrão de uma pessoa adulta: o de estar casada.

Uma oposição pode deixar isso claro. Se, como vimos, o solteiro é tsipe, "um, sozinho", a palavra para "casal" é mukũĩ. Esse é justamente o termo araweté para o numeral "dois". Temos então um par de números, 1 e 2, cada um designando também uma disposição relacional. O tsipe é "sozinho", o mukũĩ é "casal" - e o dois contrapõe-se ao um da mesma forma em que o "casal" contrapõe-se ao "sozinho". É nesse sentido que tsipe-te ("verdadeiramente sozinho") é uma boa qualificação do solteiro, próxima à primeira noção de jije que descrevi: alguém "sozinho" está sem uma companhia. O dado é estar acompanhado, e a companhia fundamental de um adulto - ou, no mínimo, a usual-é o dois, o casal: o marido e a esposa, que, como acontece frequentemente no dia a dia da aldeia, andam juntos. O solteiro ou a solteira, que fique claro, não andam sozinhos pela aldeia: eles estão sempre com outros jovens de sua idade. Porém, são companheiros, não cônjuges, e suponho que seja por isso que os Araweté afirmam que os jijehã são sozinhos. É o casal o elemento de fundo para compreender o solteiro, pois jijehã parece ser definido pela sua contraposição, o par. Assim, um solteiro é um "não-par", ou um "antes" do par.

Mas se falta ao jijehã seu par, nem por isso ele é "pitiable". Ao contrário, é nesse momento, segundo mulheres e homens araweté, que rapazes e moças são mais bonitos, que algumas garotas ficam mais gordas, que rapazes só saem para caçar ou pescar quando querem, que acordam tarde e que passeiam mais livremente pelo território. Eé também nesse momento que-segundo dizem - jovens jijehã têm mais liberdade sexual e amplitude de parceiros. Tudo isso nos introduz ao segundo sentido da noção de jije de que falei, a de "inteireza" ou "unidade". Sem par, sozinho, o jijehã é uma singularidade. Mas como o porco ou o fardo inteiros, ele é uma unidade que é também múltipla. Por não ter atualizado determinadas ligações, essa unidade contém em si uma potencialidade virtualmente infinita. Homem ou mulher, o solteiro é sozinho, mas isso não faz dele sem companhias. Ele é um não-par, mas exatamente por isso ele tem uma 
multiplicidade parceiros: ele tem um conjunto de pretendentes concomitantes e concorrentes. Ele é um feixe de relações possíveis.

Por não terem ligações matrimoniais, os jijehã são em certa medida móveis. Quando podem, eles não andam com seus pais. Eles pegam carona em voadeiras de outras pessoas - cunhados, irmãos ou irmãs mais velhos ("classificatórios" ou "reais") com seus cônjuges, pais e mães "classificatórios", entre outras possibilidades - para passeios nas praias da região ou para Altamira. Eles também não dormem nas casas de seus pais. Os meninos têm suas casas construídas separadamente - é vizinha à deles, mas com um grau de autonomia topologicamente marcado. Também as meninas: elas dormem em casas separadas, ou, quando possível, na casa de parentes (como avós viúvas). Eles ou elas geralmente comem com os pais, mas nem sempre-muitas vezes acabam tornando-se frequentes em refeições em outros pátios. O ponto é que os solteiros e, em menor escala, as solteiras, gozam de uma relativa autonomia (cf. também Cow, 1991: 129ss.; Pissolato, 2007: 127, 147ss.). Eles são crescidos (ou melhor, odzi mohi-re, "se fizeram criar"), já "sabem tudo", e suas relações com seus pais passaram idealmente por um afastamento contínuo e gradual e sustentam agora um distanciamento máximo, embora em certa medida controlado ${ }^{3}$.

Os solteiros andam geralmente com outros solteiros. Parece haver na verdade "levas" de solteiros. Entre dezembro de 2011 e janeiro de 2012-durante um período do trabalho de campo que realizei na aldeia Juruãti - havia vários rapazes e moças iniciando flertes e experiências matrimoniais. Passavam por tentativas que davam preferência para pretendentes da mesma aldeia, e, quando não mais possível, jovens de outras. Já em março de 2013, surpreendeu-me o fato de só haver uma menina que consideravam jijehã. Ela, no ano precedente, mal tinha olhos para rapazes e dizia nem querer se casar; já no ano seguinte, quase não segurava suas paixões. Mas então, em seu triste estado temporão, já não havia rapazes casáveis: exceto por um irmão solteiro (FBS), os meninos eram todos muito pequenos, crianças ainda.

Alguns meses depois, surgiu uma nova leva. Isso ficou claro para mim quando, após uma ida à cidade, voltei com fotografias impressas para entregar a seus donos. Antes de distribuí-las, eu passeava pelas casas carregando-as, pois havia percebido que, além de apreciarem analisá-las e fazer gracejos a partir delas, homens e mulheres também gostavam de me ensinar sobre suas relações de parentesco por meio das imagens. Isso me permitiu vislumbrar quais tipos de ligações eles decidiam traçar espontaneamente, sem que eu perguntasse, e também o potencial que essas suas associações possuíam para me fazer compreender de outro modo suas noções relacionais. Nesse contexto, eu era frequentemente interceptada por grupos de meninos e meninas que até então me pareciam crianças, mas nos quais agora eu começava a perceber traços da
3 Parte da descrição que fiz na minha tese de doutorado (sobre a criação de novas pessoas entre os Araweté) dedicou-se a este processo: de que os filhos e filhas vão, à medida que crescem, separando-se do núcleo residencial de seus pais. Isso começa a acontecer desde os primeiros passos da criança, mas-pulando parte substancial desse percurso-é na época do nascimento de um filho próprio (i.e., quando aquele bebê cresceu, virou um jijehã, casou-se e teve, por sua vez, um filho) que enfim se consuma tal destacamento. 
puberdade. Chegavam até mim com seus "amigos" (para os homens) e "amigas" (para as mulheres), quase sempre em duplas ou em pequenos grupos, ansiosos por achar na pilha as imagens específicas daqueles ou daquelas que Ihes interessavam. Quando a pareciam, eram recebidas com risinhos, chacotas e, sem exceção, por pedidos: queriam guardar para si as fotografias dos "namorados" ou "namoradas", como gozavam os amigos. Mas raramente tratava-se de um só: cada jovem queria possuir várias imagens de pretendentes atuais ou passados, solteiros ou casados, de sua idade ou mais velhos.

Foi nesse momento que mais ouvi falar de "gostar", palavra que tem como correspondente em seu idioma o verbo - putã ("gostar, querer"). Mas ouvi também de "paixões" e "amores", assim como de um vasto repertório romântico em português que tem ficado cada dia mais frequente por via de novelas do "horário nobre", das canções de Roberto Carlos e de estilos musicais como sertanejo universitário e tecnobrega. Foi nesse momento também que aprendi que os flertes atuais entres solteiros e solteiras se dão muitas vezes na língua portuguesa, principalmente "quando tem muito velho perto", me disseram, que é "para ninguém entender". Pelo mesmo motivo, usam apelidos, geralmente nomes de brancos, às vezes com alguma semelhança sonora com o original. No entanto, o disfarce não é muito eficaz: o português é entendido pela maioria dos Araweté (exceto por crianças muito pequenas ou por idosas e idosos) e os apelidos não são tão cifrados quanto se gostaria. Assim, muitos desses flertes, que se pretendiam secretos, são conhecidos pela maior parte dos adultos, os pais e as mães dos jovens inclusive. Normalmente os adultos fazem pouco caso, exceto quando há motivos para maiores fofocas, como em uniões possivelmente incestuosas, em suspeitas de gravidez da moça ou quando a menina é tida como muito pequena. Na maior parte das vezes, os pais também negligenciam os flertes, pelo menos até que um rapaz ou uma moça recrute coragem e intermediários para ir aos futuros sogros e informá-los do desejo de efetivar o casamento, ou, em casos mais infelizes, até que as fofocas alheias incomodem os ouvidos parentais.

Uma das coisas que faz os flertes tornarem-se manifestos é a retribuição de sorrisos aos gracejos do pretendente. Ensinaram-me que uma mulher não ri para um homem quando não se interessa por ele e, de fato, assim faziam muitas delas quando eram alvo de brincadeiras indesejadas: fechavam a cara e olhavam para outro lado. Em geral as mulheres araweté, tanto quanto os homens, andam prontas a devolver alguma simpatia recebida - o sorriso é frequente, embora não um sorriso "saliente". A falta de sorriso é um sinal de interrupção no fluxo das relações cotidianas, por isso, quando evitam o sorriso, há motivos - em geral envolvendo rixas implícitas ou brigas explícitas com corresidentes. As investidas indevidas de um galanteador podem ser também tomadas como inconvenientes, sendo então respondidas com hostilidade. Mas solteiros e solteiras-sobre- 
tudo mais velhos - podem não ser muito parcimoniosos em suas réplicas e em seus sorrisos.

Um caso é ilustrativo: certa tarde, uma jovem me contava em português sobre o rapaz por quem ela era apaixonada. Eles são namorados, ela me dizia. Recentemente, eles haviam se encontrado em uma das aldeias, por ocasião de um torneio de futebol. Eles não conversaram - os amigos dele é que geralmente vinham falar com ela, dar recados, às vezes bilhetes ou presentes. Perguntei se ela e o pretendente riam um para o outro quando se viam: "Quando ele vem eu fico nervosa. Eu rio muito para ele", ela respondeu. Poucos segundos depois, porém, ela acrescentou: "Eu dou sorriso para todos os meninos. A gente não dá sorriso para qualquer um? Eu fico rindo para eles". E logo em seguida ela me convidou para fazer as contas do número de "admiradores", como ela disse, que possuía pelas aldeias. Três do Aradyti, dois do Juruãti, dois do Pakãñã e um do Ta'akati-oito no total, eu disse.

A jovem não tinha vontade de se casar com nenhum dos seus oito pretendentes, a não ser com aquele por quem era apaixonada. Todavia, isso não a impedia de conceder certa abertura aos outros. Sem um laço efetivo de matrimônio, nada a restringia, nem mesmo o ciúme distante de seu namorado. Aliás, outros poderiam até mesmo ser chamados de namorados em outras circunstâncias, sem que aquele deixasse de sê-lo. Ela era jijehã, termo que aqui que empresta sentido das duas acepções que já vimos: seja no de sem um par, seja no da multiplicidade virtual de suas relações. Quanto aos oito solteiros, também eles - ao menos os que eu conhecia - tinham uma ou mais pretendentes preferidas, mas eventualmente mostravam interesse pelas outras. Faziam isso por meio das brincadeiras, às vezes também por papeizinhos na escola (quando estão na mesma aldeia), mas ocasionalmente também entregavam algum presente em segredo: um pen-drive com músicas de pajé e de branco ${ }^{4}$, óleos e cremes de cabelo, anéis, correntinhas. Percebi ser também comum rapazes presentearem moças com comidas, como peixe, jaboti, açaí - mas, nesse caso, segundo entendi, entregam-nas diretamente aos possíveis sogros, não à jovem. Isso torna o flerte escancarado, o que não é sempre a vontade dos jovens e é tomado com o início de uma investida matrimonial. Em todo caso, nenhum interesse será tomado como comprometimento até uma manifestação direta.

A minha impressão então é que, quando surgia uma leva de solteiros, havia um conjunto de jovens com inúmeras possibilidades de associação entre si. Nenhum dentre os casáveis era absolutamente descartado por um solteiro ou uma solteira até que uma dessas possibilidades fosse efetivada. Evidentemente, isso é uma generalização, e não posso desconsiderar preferências ou aversões individuais, ou mesmo as influências de pais e mães mais incisivos. Em todo caso, mesmo essas inclinações podiam acabar sofrendo alterações com o tempo, já
4 Guilherme Heurich conta, em sua tese de doutorado (2015), sobre a tecnologia adotada pelos Araweté a partir do trabalho de campo do autor. Amantes de músicas, os Araweté começaram a fazer uso da reprodução em rádios a pilha, por meio de gravações em pen-drives, de variados tipos de músicas - não apenas as tradicionais entoadas por xamãs em ocasiões rituais, mas também vários estilos de músicas "de branco". 
que normalmente cada jovem ensaia seguidas tentativas de casamentos e novos parceiros são experimentados a cada separação.

Além das levas de surgimento de solteiros, também havia "ondas" de efetivação de casamentos: um começa e outros o seguem. Com tais levas, aliás, tudo se passava um pouco como na distribuição de um porco ou um fardo: enquanto a distribuição é virtual, todas as possibilidades existem; quando, porém, um "corte" inicial é dado - ou seja, quando um primeiro par se efetiva, destacando-se da "leva" dos solteiros - várias outras uniões o seguem. O problema é que, dentre os vários jijehã, alguém tem que decidir começar. Aquela mesma jovem dos oito admiradores me havia dito que seu pretendente não queria tenotã, "iniciar", o movimento. Ele iria esperar - como aliás a maioria dos e das jijehã acaba fazendo - até que outro tomasse a iniciativa. De fato, há algo como um prolongamento "até o ponto máximo" da espera (Viveiros de Castro, 1986, cap. 2), que é atentamente monitorado por todos através de uma comunicação frequente entre os solteiros, quase sempre por via de amigos intermediários, muitas vezes pelo sistema radiofônico. Os recados cruzados constantemente incitam ciúmes nos rapazes e nas moças, e cada um vislumbra sempre a "quase possibilidade" da efetivação do casamento do pretendente desejado com um oponente. Esse imbróglio só se resolve quando alguém finalmente vence a timidez, ou, eventualmente, quando alguém se cansa da espera, ou se faz alheio a ela, ou se adianta frente a uma possibilidade iminente não muito interessante-em todo caso, alguém rompe a inércia e inaugura o movimento (iipipe, "o primeiro"), e então outros casamentos o seguem. Mas pouco haverá de permanente nisso, pois é muito comum que os casamentos de jovens sem filhos se atem e se desatem em sequência, cada vez com arranjos renovados. Só com o nascimento do primeiro filho uma união se estabiliza.

\section{O PAI EGoÍSTA,}

\section{O SOLTEIRO JAGUAR}

Posso ter dado a entender, com as descrições acima, que moças e rapazes solteiros gozem de completa liberdade de escolha de seus cônjuges. Não é bem assim que se passa. Em relação a alguns outros contextos etnográficos, tanto rapazes quanto moças têm aqui, é verdade, grande autonomia dentre a esfera genealógica permitida. Mas não é possível desconsiderar que há uma grande variedade de casos específicos, sendo difícil resumir a uma simples descrição. A criatividade dos arranjos matrimoniais dos Araweté é grande, sobretudo porque prescrições matrimoniais específicas são pouco frequentemente sublinhadas por eles como normas para ação (ver também Viveiros de Castro, 1986: 42, 109, 405ss.).

É claro que rapazes e moças conhecem desde cedo a trama de possíveis 
alianças que os envolve. Ainda que não se explicitem regras positivas de casamento, há estratégias matrimonias desenhadas por uniões prévias (dos pais ou irmãos mais velhos) que tanto excluem quanto favorecem certas uniões. Alguns jovens, homens ou mulheres, possuem efetivamente muita liberdade de escol ha e podem seguir de maneira relativamente livre seus desejos matrimoniais. Nesses casos, somente situações grosseiras de incesto são limite. Já outros jovens nem tanto: certas moças e rapazes têm de se fazer sensíveis também às inclinações de seus pais. Os jijehã podem se adaptar ou tentar se furtar a tais inclinações parentais (ou de outros parentes); em todo caso, semelhantemente ao que notou o casal Murphy para os Munduruku (1985:175), se um ou uma jovem se opõe radicalmente às intenções dos pais, essas são postas em dúvida e sua recusa costuma ser ouvida. É também frequente que o próprio solteiro progressivamente se acostume com a ideia, deixe-se em dúvida, ou, no mínimo, contemple a possibilidade de cônjuge indicada pelos pais.

Mas há pais mais firmes, ou hatĩ me'e, "duros", como diriam os Araweté. Se não o são com todos os filhos, ao menos com alguns, caçulas principalmente. As filhas ou os filhos mais novos costumam se casar bem mais tarde, pois "ficam ajudando" os pais até uma idade mais avançada, chegando às vezes até cerca de 25 anos. Quando são mulheres, elas são responsáveis por lavar as roupas, cozinhar, carregar água, buscar lenha; quando são homens, por prover peixes (e eventualmente caça, mas nem todos os jovens começam cedo a caçar), pilotar embarcações e auxiliar em assuntos na cidade, como nas compras; ambos também ajudam na roça. Quando não se trata de caçulas, e especialmente no caso de mulheres, se a irmã que a sucede é ainda pequena e não pode se responsabilizar por parte das tarefas domésticas, a solteira terá de esperar até que a menor cresça, especialmente se for deixar o pátio dos pais para morar com os sogros. Em alguns casos, todavia, não há grandes explicações para o adiamento de alguns enlaces, e presenciei situações desse tipo tanto com moças quanto com rapazes (embora seja muito mais comum com elas). Nesses casos, as razões dos pais são alvo de especulações variadas, e ouvi algumas que vão desde um pai só liberar a solteira para um "rico" - que, no contexto araweté, trata-se de alguém que dispõe de salário (professor, Ais ou Aisan) ou aposentadoria - até ele "não querer largar a filha".

Contavam-me frequentemente sobre meninas mantidas sob espreita de pais e mães. Casos como estes inspiravam comentários, principalmente por que os solteiros - homens ou mulheres - são investidos, ao menos idealmente, de uma maior liberdade de movimentação. Essa mobilidade é relevante aqui, pois nos remete novamente ao conceito de jije. Eu dizia que jijehã são em certa medida móveis, estão relativamente destacados de parentes consanguíneos próximos, mas ainda sem vínculos efetivos de aliança. Todavia, nem todos os 
pais e mães consentem tal separação.

Um caso que presenciei é ilustrativo. Trata-se da história de uma jovem cujo pai não era receptivo ao casamento que ela desejava. O que se passava era que o garoto visado era caçula de uma viúva idosa e, nesse caso, era sabido que aquela que o desposasse teria de morar perto da sogra. O pai da moça não aceitava a mudança da filha; ao mesmo tempo, os outros possíveis cônjuges eram ainda considerados crianças. O pai então restringia seus movimentos. Sua história passou a ser mencionada em tom de fofoca entre corresidentes próximos, alguns condenando a contenção. A garota me disse que um de seus pais (um FB) não se conformava com a situação e observou em contraposição: "Eu não sou igual seu pai. Eu sou outro, eu não ia deixar você sentada assim. Eu deixo minha filha sair".

A oposição é central: "andar", "passear", "sair", por um lado, e "sentar", por outro. A restrição dos movimentos de solteiros, como aconteceu no caso aci$\mathrm{ma}$, aparece como esforço de frear ou contrariar a uma marcha de certa forma prevista no desenvolvimento púbere. "Sentar-se" (-api) é o que mulheres devem fazer quando já são casadas e esperam o retorno de seus maridos dentro de suas casas. Já as solteiras, não: elas ainda não têm marido, mas já não deveriam estar sob espreita de seus pais. O comentário sobre a imobilidade da solteira não faz mais que evidenciar que é esperado que uma solteira "ande" - ainda que o esperado nem sempre, ou mesmo poucas vezes, seja o que de fato acontece.

Em todo caso, é comum que a partir dos doze ou treze anos meninas e meninos se engajem em uma série de casamentos tentativos, separando-se várias vezes e reexperimentando com novos pretendentes. Portanto, é comum que solteiros estejam sem cônjuge não só por ainda não terem experimentado um casamento, mas também por terem acabado de desatar um laço, ou mesmo por terem já experimentado todas ou todos os parceiros possíveis até o momento (i.e., parceiros casáveis, disponíveis e interessantes um ao outro e às suas famílias). No caso de meninas, um outro fator acarreta um estado prolongado de celibato: algumas jovens apresentam desde cedo a preferência por um rapazote específico e resolvem esperá-lo até que ele chegue a uma idade minimamente casável; só então elas o desposam, "criando" o menino até torná-lo adulto. Não tive conhecimento da versão contrária ${ }^{5}$.

É comum, então, vermos jovens que se encontram solteiros ou solteiras até uma idade mais avançada (jijehã-oho, lit. "solteirão", palavra que só ouvi para o feminino, "solteironas"). E, sobre esses, há algo interessante a notar. Enquanto pequenos, ainda no limiar entre serem ou não tidos como jijehã, meninos e meninas raramente são alvo de muita atenção das fofocas da aldeia. Já quando mais velhos, passam a ser protagonistas preferidos de conversas envolvendo intrigas sexuais, como traições, ciúmes, libido, gravidez.

Não há grande novidade aqui. Outros antropólogos e antropólogas já desta-
5 Como é comum também a outros contextos etnográficos, ainda acontece o casamento de homens adultos (normalmente viúvos) com jovenzinhas, como descrito por Viveiros de Castro (1986: 453), mas era muito mais frequente na época em que o autor realizou seu trabalho de campo 
caram em diversos contextos ameríndios a sexualidade acentuada e não-dirigida de que solteiros são frequentemente investidos (Huxley, 1963: 147; Murphy e Murphy, 1985: 172; Métraux, 1979: 120, Gow, 1981: 132, 133; Rosalen, 2005; Garcia, 2010: 184Ss.; França, 2012). Em alguns casos, evidencia-se um certo perigo envolvido em sua figura. "Um celibatário é como um jaguar na comunidade", afirmou Pierre Clastres (1995: 112), quando notava a ameaça encarnada em rapazes aché que se excedessem no tempo de pravoty, "seduzir as mulheres": ao recusar o casamento, um jovem se tornaria fonte de problema "ao mesmo tempo para os casados cujas esposas ele ameaça e para os iniciados mais jovens que esperam a sua vez" (1995: 111).

É verdade que nem sempre o solteiro-sedutor araweté oferece um real problema, mas em todo caso é comum falar-se desses rapazes que, já há alguns anos da puberdade e sem cônjuge, presumivelmente não se mantêm castos. $A$ presunção não é minha: para cada rapaz jijehã acima de seus 15-17 anos, supunham-se vários flertes. Um jovem, por exemplo, foi em um mesmo momento apontado como "namorado" de uma menina, pai do filho de outra, "amante" de uma casada e destinado ao casamento com outra solteira. De um outro garoto, ainda por volta dos 13 anos, um adulto dizia-me rindo ao observar sua foto: "esse daqui está roubando minha mulher". É certo que algumas vezes a não-efetivação de um matrimônio pode consistir em uma opção-tomada por homens, não mulheres - para que se possa desfrutar mais do estado celibatário. Diziam-me por exemplo que antes das aldeias se cindirem, quando a população Araweté morava reunida na aldeia do Ipixuna (i.e., até 2005), havia um desequilíbrio demográfico, com a maioria da população jovem feminina: como havia muitas solteiras, "homem não queria casar muito cedo, ficava só namorando. A mulherada ficava velha, tudo jijehã".

Mas não só os homens, como também mulheres jijehã são marcadas pela sexualidade exacerbada. Esse não é o discurso das próprias solteiras sobre si mesmas, é verdade; isso não impede, porém, que elas figurem nas conversas alheias como acessíveis a homens solteiros ou casados, da mesma aldeia ou de outras. Ou mais: que elas apareçam como desejantes de tais conexões. Ouvi algumas vezes brincadeiras sobre a forte libido sexual das solteiras. Quando isso acontecia, outras mulheres presentes também riam, mas não era nesses termos que elas próprias se referiam à lascívia das solteiras. Em tom de fofoca, elas geralmente contavam histórias de jijehã com homens casados. Pois, fato é, se as solteiras não têm cônjuge, com outros homens elas devem se relacionarjá que seria impossível, ou assim supõe-se, que elas não o façam com ninguém. O falatório versava então sobre histórias que tinham maridos alheios como protagonistas.

O ponto é que a "abstinência sexual" não é concebida pelos Araweté para 
adultos a não ser em casos específicos: no resguardo pós-parto (ou pós-homicídio, quando havia guerras), durante a menstruação e para um pajé em frequente atividade xamanística. O importante, em relação a isso, é perceber como a sexualidade irrestrita dos homens e mulheres jijehã nos faz retomar aquilo que notávamos sobre o conceito de jije. E aqui, novamente, a comparação com o casal (mukũĩ) nos é útil. Para os casais, ambos os cônjuges têm vetores específicos, mais ou menos institucionalizados, a quem sua sexualidade é normalmente dirigida. Pois um casamento não é um affair apenas do casal, mas compreende também uma série de "amantes", como dizem alguns jovens em portuguêsdesde que, contudo, com o assentimento mútuo entre marido e esposa.

Para começar, são permitidas relações sexuais com irmãos do marido (classificatórios e reais), para ego feminino, e irmãs da esposa (classificatórias e reais), para ego masculino. De fato, há uma espécie de "equivalência" sociológica entre germanos de mesmo sexo (ver Viveiros de Castro, 1986: 413ss.), o que implica, em correspondência, uma equivalência entre: do ponto de vista da mulher, o marido e seus irmãos (que são chamados de terekũ idõ, "outro/novo marido", ou "marido 'substituto"' na glosa de alguns jovens); e, da perspectiva do homem, entre a esposa e suas irmãs (chamadas de temijika idõo, "outra/nova/substituta esposa"). A equivalência de tais posições torna as relações sexualizáveis. Ou seja, o sexo entre "cunhados/as" (HB e ZH, para mulheres; e WZ e BW, para homens) não é apenas permitido, como eventualmente também estimulado (ainda que, não raro, o ciúme toma indevidamente parte da trama - ver também Calheiros, 2014:181 n.187).

Além disso, podem-se travar relações de apihi-pihã: a "amizade formal" entre dois casais não aparentados, a partir do consenso entre cada par de marido e esposa (já bem descrita por Viveiros de Castro, 1986: 422-437 principalmente). A troca envolve o compartilhamento de refeições, mas também de brincadeiras, cuidados e camaradagem entre seus quatro componentes. Os pares de mesmo sexo tornam-se - quando moram na mesma aldeia ou quando se visitam - companheiros em atividades cotidianas: as mulheres vão juntas lavar roupas e vasiIhas, às vezes tecem em conjunto suas tupãî (saias), os homens (que se chamam de apihi pihä) saem juntos para pescar ou caçar. Já os pares de sexo cruzado (i.e., as mulheres e seus apĩno; os homens e suas apihi) passam a ter, durante um período, uma relação erótica. Se tal amizade formal não é tão corriqueira como pode ter sido em outra época, ela continua sendo, de longe, a relação sexual que mais recebe atenção por parte dos e das Araweté: é a de que mais gostam de falar, a que explicam com mais detalhes e, certamente, a maneira preferida de ativar vínculos extraconjugais?

Ademais, é bastante frequente que homens casados tenham relações sexuais esporádicas com outras mulheres, a maior parte das vezes com moças
6 A palavra apihi-pihã é na verdade o termo utilizado para o endereçamento mútuo entre homens. Apihi é a forma como o homem se dirige à sua "amiga" - ou "amante", como têm também traduzido os Araweté. Se é mesmo possível analisar o significado de termos de parentesco, poderíamos dizer que ele pode ser decomposto em apĩ, "filho/a" + e hi, "mãe": "mãe de filho/a", isto é, o tecnônimo para as mulheres em quem um homem, por via desta amizade formal, ajuda a fazer filhos. As mulheres chamam os homens de apĩno, no, "pai", então "pai de filho/a". Quando um homem chama um outro de he apihi-pihã, ele o está chamando de "companheiro" (pihã) de minha "mãe de filho". As mulheres, diferentemente, não empregam um vocativo entre si. Se têm de fazer, elas empregam a mesma versão masculina (em vez de uma inexistente equivalência feminina, como apĩno-pihã) - o mesmo apihi-pihã que dá o nome da relação quando os próprios Araweté a mencionam em conversas ou relatos.

7 É interessante que não é chamando de "cunhado" que os Araweté incorporam um forasteiro, como fazem outros povos ameríndios. Tampouco ele é integrado imediatamente à rede de parentesco, por intermédio da utilização de vocativos como "filha/o" ou "irmã/ão". Antes, alguém desprovido de qualquer vínculo de parentesco entre os Araweté é, por excelência, um tiwã (termo para primo-cruzado), um afim, mas "avulso", por assim dizer, ao complexo das redes de parentesco-logo, um parceiro sexual potencial de todos e qualquer um. 
solteiras. Isso não é detalhe. Presenciei situações em que a esposa incitava o marido a procurar determinada mulher: uma vez, por exemplo, uma comentou algo com o marido em baixa voz e, em seguida, ela se virou para mim e explicou, rindo, "ele vai namorá-la hoje". Até onde soube, o contrário raramente se dá com mulheres-ou, pelo menos, elas não o admitem abertamente. Em todo caso, só há uma condição: o consentimento do cônjuge. Um ato sexual travado à revelia do conhecimento da esposa ou do marido ("fazer segredo", como dizem) será fonte de ciúmes e brigas.

O ponto é que há variadas formas de atualizar relações sexuais sem restringir-se ao cônjuge - formas que são (idealmente) legitimadas entre os esposos. $O$ casamento irá institucionalizar o vínculo sexual entre um homem e uma mulher, mas também irá criar, pela sua própria ativação, uma rede de relações sexualizáveis "paralela" a ele: entre cunhadas/os, entre apihi e apĩno e com eventuais parceiros acordados pelos cônjuges.

Em contrapartida, um jijehã, homem ou mulher, não tem parceiros sexuais instituídos. Ao mesmo tempo, parece ser inconcebível que ele se abstenha de conexões sexuais. Se ele não se encontra dentro de uma rede de sexualidade estabelecida pelo casamento, supõe-se que ele deva travar relações fora dela, ou melhor, isento dela. Pois um jijehã não travou efetivamente uma relaçãoisso faz com que ele possa ter, de certo modo, uma multiplicidade de relações. Dizíamos da caça jije ("inteira") que ela é infinitamente maior que seus pedaços, já que nela estão contidas, virtualmente, todas as possibilidades de sua distribuição. Sua divisão em uma "quantidade" é também um corte da multiplicidade. A analogia com o jijehã não é distante.

O solteiro não é "dois" (mukũĩ, um casal), nem um múltiplo de dois (isto é, a pluralidade que vem a partir do casamento); ele é "um", tsipe, que significa também "sozinho". Se isso faz dele desprovido de um cônjuge, não por isso ele é desprovido de outras relações eróticas e afetivas. Não estando em uma rede atual de aliança criada pela efetivação de um matrimônio, ele é um feixe de virtualidade com possibilidades que coexistem sem excluírem-se. A pluralidade própria da conjugalidade lida com possibilidades concretas decorrentes de uma ligação matrimonial - sendo que todo vínculo sexual fora dessa deve idealmente ser acordado entre o casal. A condição celibatária, em contrapartida, tem toda a afinidade como espectro relacional. Pois não se pode dizer que um jijehã tem "vários" parceiros (i.e., uma "pluralidade"), porque o que ele tem é a virtualidade de "múltiplos", e a imprecisão é fundamental à sua simultaneidade - há espaço na multiplicidade para antagonismos e incompatibilidades. Ele pode atualizar seus flertes em diversas aventuras sexuais, mas é impossível que estas sejam definíveis e quantizáveis, até porque nenhuma pode ser durável. É verdade que a jovem dos oito pretendentes os enumerara precisamente naquela ocasião, 
mas aqueles eram todos os seus vínculos matrimoniáveis no momento-pouco tempo antes havia outros e depois apareceram mais. Mas seu leque de relações sexualizáveis era incalculável, pois havia também homens casados que insistentemente a visavam (aliás, com ou sem o consentimento de suas esposas) para arranjos momentâneos - e era por meio desse cenário sexual múltiplo que ela, como solteira, era encarada.

$\mathrm{Na}$ esteira de Clastres, não seria destoante afirmar que solteiros e solteiras assumam uma posição de "jaguar", sobretudo quando damos ênfase a sua sempre possível predação sexual. Essa analogia não é dos Araweté, nunca ouvi falarem de solteiros como jaguares; em todo caso, ela não deixa de ser elucidativa, principalmente se considerarmos a equivalência da linguagem culinária e sexual também no idioma desses índios ${ }^{8}$ : alimentar-se e ter relações sexuais podem ambos ser ditos "comer" (-0). Nesse sentido, jijehã são comedores.

\section{CONCLUSÃO}

Eu tratei ao longo deste artigo dos modos de relação de solteiros e solteiras Araweté descrevendo os dos dois sentidos de jije contidos no termo jijehã: aquele que descreve os elementos que deveriam estar juntos, mas estão separados (como o caçador sem caça, a mulher sem roupa etc.); e o dos elementos que estão inteiros, mas deveriam ser distribuídos (porco inteiro; fardo fechado). A esta altura, parece ser possível divisar uma conexão entre estes dois sentidos.

Vimos que, como acontece aos caçadores sem caça ou à mulher sem roupa, também aos jijehã falta-lhes seu complemento essencial - eles estão "sozinhos", "nus", "desacompanhados". Solteiros e solteiras são "desvinculados", e, assim sendo, eles possuem uma espécie de "carga negativa": nada estáveis, eles têm uma tendência a vincular-se indiscriminadamente. $O$ "negativo", suponho estar claro, não descreve qualquer "carência" moral, convivial ou o que seja. Ele não é repulsivo, é atrativo: converge para si um interesse radical, é foco de desejo-os jijehã são bonitos, sedutores, sexualmente acessíveis. Assim, antes de qualquer coisa, a condição "negativa" aponta para essa propriedade de uma pessoa ser constituída não somente de vínculos efetivos, mas também da virtualidade de laços - neste sentido, ela aproxima os jijehã daquela singularidade indivisa do porco ou do fardo inteiros. Mas tal condição "negativa" nos lembra ainda de outras propriedades do estado jijehã -como, por exemplo, a de serem constituídos/as também pelas atualizações efêmeras de vínculos, como nos flertes; ou, igualmente, por todas as dinâmicas relacionais para que se travem futuras conexões. Isto é, tal condição dos jijehã implicaria, em certa medida, também o movimento para novas vinculações.

As duas acepções de jije parecem apontar para algo em comum. Afinal, em
8 Cf. Viveiros de Castro (1992: 269, n.4). Como se sabe, isso não é incomum: a conhecida resposta de mulheres sharanahua a Siskind o explicita de uma forma fascinante: "there's no meat, let's eat penises!" (1973: 105). Ver também os gulosos animais-sedutores dos Wajãpi (Gallois, 1988: 141) e, para a relação entre comida e sexo, Lévi-Strauss (2004: 309). 
que sentido algo "sem o seu complemento" se aproximaria daquela "singularidade" própria do porco inteiro ou do fardo fechado? Isto é, não são aqueles também espécies de "unidades", como estes? Pois o caçador está sem caça, a mulher está sem roupa. Ambos são singularidades, e, por sê-lo, eles também são instáveis, pois é forçoso que travem novas conexões: o caçador tem de comer, a moça tem de se vestir. Então, assim como o porco inteiro ou o fardo, que são investidos de uma multiplicidade relacional (virtual), mas ao mesmo tempo indiferenciados no que diz respeito a vínculos atuais, aqueles não estariam também abertos à efetivação de relações? Não seria então possível entrever, nos dois sentidos de jije, essa mesma condição de "unidade" que é também um estado "antes" da conexão - isto é, um estado em que se evidencia a possibilidade das relações, bem como os movimentos para travá-las?

No caso dos jijehã, sendo eles também "unidades", será o futuro cônjuge quem irá trazer a eles seu complemento. Quando dois solteiros se unem, porém, uma nova junção irá aparecer - e esta será, também, uma nova espécie de unidade. Pois aquela unidade solteira era, em certo sentido, uma "unidade plana": sem sua conexão efetiva com um "outro", ela era "idêntica a si mesma" - isto é, uma replicação interna e constante de suas possibilidades múltiplas. Era instável, mas também era transitória: com efeito, cedo ou tarde, supõe-se que tal condição será superada, pois uma aliança eventualmente se efetivará. Quando isso acontecer, quando dois solteiros se juntarem e, sobretudo, quando nascer seu primogênito, surgirá uma nova forma de convivência: o "par". Esposa e marido terão uma casa, andarão sempre juntos pela aldeia, realizarão conjuntamente atividades cotidianas e cultivarão diversas formas de relação enquanto casal. 0 par araweté é também "um par", isto é, ele é uma "unidade dual".

Diferentemente daquela unidade plana do jijehã, o par não resultará em uma "identificação" entre esposa e marido. Isto é, a nova unidade criada não será internamente homogênea. Um cônjuge irá acrescentar ao outro um complemento diferencial ${ }^{9}$. A começar, claro, pela dessemelhança fundamental entre masculino e feminino: as pessoas unem-se com sua contraparte sexual, e é isso o que possibilita a criação de um novo ser - a mulher fará, em seu interior, a transformação do sêmen do marido em "filho/a". Mas não apenas isso. De fato, como insistem os Araweté, a única condição inequívoca para a matrimonialidade é precisamente a alteridade sociológica entre os cônjuges. Isto é, esposa e marido devem ser amute, "outros", entre si. Pois o mesmo é incestuoso, e não apenas sociologicamente, mas também conceitualmente. Já a união entre diferentes é o que impele a transformação, a troca-é a diferença interna possibilita a criação: de relações, de alimentos, de casas, de cotidiano, e, principalmente, de novas pessoas.
9 Aliás, assim como a roupa para a mulher ou a caça para o caçador. Para uma discussão muito interessante e já bastante consolidada sobre um e múltiplo, identidade e diferença remeto a Clastres (2003) e Lima (1996). 
Camila Becattini Pereira de Caux formou-se em Ciências Sociais pela UFMC e é mestre e doutora em Antropologia Social pelo PPGAS/Museu Nacional-UFR].

\section{REFERÊNCIAS BIBLIOGRÁFICAS}

\section{CALHEIROS, Orlando}

2014 Aikewara: esboços de uma sociocosmologia tupi-guarani.

Rio de Janeiro, tese de doutorado, UFR].

\section{CLASTRES, Pierre}

2003 "Do um sem o múltiplo". In A sociedade contra o Estado. São Paulo, Cosac \& Naify.

1995 Crônicas dos índios Cuayaki: o que sabem os Aché, caçadores nômades do Paraguai. Tradução: Tânia Lima e Janice Caiafa. Rio de Janeiro, Editora 34; Nova Fronteira.

FRANÇA, Luciana

2012 Caminhos cruzados: parentesco, diferença e movimento entre os Kagwahiva. Rio de Janeiro, tese de doutorado, UFR].

\section{GALLOIS, Dominique}

1988 O movimento na cosmologia waiãpi: criação, expansão e transformação do universo. São Paulo, tese de doutorado, USP .

GARCIA, Uirá

2010 Karawara: a caça e o mundo dos Awá-Guaja. São

Paulo, tese de doutorado, USP.

GRECOR, Thomas

1985 Anxious Pleasures: The Sexual Lives of an Amazonian People. Chicago, University of Chicago Press.

GOW, P.

1991 OfMixed Blood: Kinship and History in Peruvian Amazonia. Oxford, Clarendon Press 
HEURICH, Guilherme O.

2015 Palavras quebradas, mundos citados e mortos esquecidos na arte verbal Araweté. Rio de Janeiro, tese de doutorado, UFR].

HUXLEY, Francis

1963 Selvagens amáveis: um antropologista entre os índios Urubus do Brasil. São Paulo, Companhia Editora Nacional.

LÉVI-STRAUSS, Claude

2004 O cru e o cozido. Mitológicas I. São Paulo, Cosac \& Naify.

2011 As estruturas elementares do parentesco. Tradução:

Mariano Ferreira. Petrópolis, Ed. Vozes.

LIMA, Tânia Stolze

1996 "O dois e seu múltiplo: reflexões sobre o perspectivismo em uma cosmologia tupi". Mana, vol.2, n.2: 21-47.

MÉTRAUX, Alfred

1979 A religião dos Tupinambás e suas relações com a das demais tribos tupi-guaranis. São Paulo, Companhia Editora Nacional, Editora da Universidade de São Paulo.

MURPHY, Yolanda e MURPHY, Robert

1985 Women of the Forest. Nova York/Londres, Columbia University Press.

PISSOLATO, Elizabeth de Paula

2007 A duração da pessoa: mobilidade, parentesco e xamanismo mbyá (guarani). São Paulo/Rio de Janeiro, ISA/Editora Unesp/NuTI.

ROSALEN, Juliana

2005 Aproximações à temática das DST junto aos Wajãpi do Amapari: um estudo sobre maleficios, fluidos corporais e sexualidade.

São Paulo, dissertação de mestrado, USP.

SISKIND, Janet

1973 To Hunt in the Morning. Oxford, Oxford University Press, pp. 96-109

SOLANO, Eliete

2010 Descrição gramatical da Língua Araweté. Brasília, tese de doutorado, UnB. 
ARTIco|Camila Becattini Pereira de Caux | O solteiro, o porco

inteiro, o caçador sem caça: o "um" entre os Araweté

VIVEIROS DE CASTRO, Eduardo

1992 From the Enemy's Point of View: Humanity and Divinity in an

Amazonian Society. Chicago/Londres, Chicago University Press.

1986 Araweté, os Deuses Canibais. Rio de Janeiro, Zahar/Anpocs. 
The Bachelor, the Peccary and the Hunter:

On the Arawete "One"

\section{ABSTRACT}

This article describes some aspects of jijehã - the singles - among the Arawete, a Tupi Guarani language speaking people of the middle Xingu river (Brazilian Amazon). The core of Arawete adult sociality is the couple; we will explore how the unmarried condition can be seen as a "negative" of such a state. We will examine the uses of the particle "jije" and explore how singles can be considered "singularities" composed by "relations of absence" - as they are not set in a specific alliance, they have virtually multiple relationships. We will, then, describe the relational network of young people and their mobility.

Recebido em 4 de setembro de 2016. Aceito em 30 de janeiro de 2017.

\section{KEYWORDS}

Amazonian

Ethnology,

Arawete, Singles, Flirting, Kinship. 